\title{
Economics of Alternative Fertilizer Supply Systems for Switchgrass Produced in Phosphorus-Deficient Soils for Bioenergy Feedstock
}

\author{
Mohua Haque • Jon T. Biermacher • \\ Maru K. Kering • John A. Guretzky \\ Published online: 11 October 2012 \\ (C) The Author(s) 2012. This article is published with open access at Springerlink.com
}

\begin{abstract}
Limited information is available explaining the economics of supplying $\mathrm{N}$ and $\mathrm{P}$ fertilizers on established stands of switchgrass growing in phosphorus-deficient soils. The objective of this study was to determine the most economical fertilizer supply system for producing feedstock in phosphorus-deficient soil in the southern Great Plains. Data collected from field trials conducted at two locations in south-central Oklahoma along with prices quoted by local input suppliers and custom service providers and assumptions about the farm-gate price of feedstock were used to estimate expected values for production costs, gross revenue and net return to owner's labor, management, and overhead for eight fertilizer supply systems. The systems included a zero fertilizer check system $(0 / 0)$, three P systems $(0 / 34$, $0 / 67$, and $0 / 101)$, one $\mathrm{N}$ system (135/0), and three $\mathrm{N}$ and $\mathrm{P}$ systems (135/34, 135/67, and 135/101). Random-effects mixed ANOVA models were used to determine the effects of fertilizer system on the values of total cost and net return. For the base-case price scenario (feedstock, $\mathrm{N}$ and $\mathrm{P}$ prices of $\$ 110 \mathrm{Mg}^{-1}$ and $\$ 1.28$ and $1.17 \mathrm{~kg}^{-1}$, respectively), the $135 / 0$ system was the most profitable system, producing $10.2 \mathrm{Mg}$ of feedstock and $\$ 263$ of net return per hectare. Economic results were most sensitive to the prices of feedstock, N and P. Net return was negative for all eight systems for the scenario where the farm-gate price of feedstock was
\end{abstract}

M. Haque $\cdot$ J. T. Biermacher $(\bowtie)$

The Samuel Roberts Noble Foundation, Inc.,

Ardmore, OK, USA

e-mail: jtbiermacher@noble.org

M. K. Kering

Virginia State University,

Petersburg, VA, USA

J. A. Guretzky

University of Nebraska-Lincoln,

Lincoln, NE, USA relatively low $\left(\$ 55 \mathrm{Mg}^{-1}\right)$ and prices for $\mathrm{N}$ and $\mathrm{P}$ were relatively high $\left(\$ 2.20 \mathrm{~kg}^{-1}\right)$.

Keywords Bioenergy feedstock · Economics · Nitrogen · Phosphorus $\cdot$ Phosphorus-deficient soils $\cdot$ Switchgrass

\section{Introduction}

Native to the southern Great Plains, switchgrass (Panicum virgatum $\mathrm{L}$.) has been classified by agricultural scientists and public decision makers as a leading source of cellulosic feedstock for the large-scale production of bioenergy fuels such as ethanol $[1,2]$. Once established, proper management of fertilizers is essential to maintain and sustain a high-quality, highyielding stand of switchgrass. At present, most of the published research regarding fertilizer management decisions associated with producing switchgrass feedstock has focused mainly on nitrogen $(\mathrm{N})$ as the primary limiting nutrient [3-6]. And more to the point, the majority of these studies focused on the agronomic implications associated with fertilizer applications, but did not investigate the economic benefits and costs associated with them. Moreover, the majority of these studies were conducted in conditions where soil phosphorus levels were determined to be adequate; that is, they were deemed to be non-yield limiting or prohibiting the economic potential of the crop.

There is a limited body of published research that evaluated switchgrass yield response to fertilizers in phosphorusdeficient soil, and the results are mixed. For example, Muir et al. [7] found that biomass yield produced in phosphorusdeficient soils did not respond to applications of phosphorus (P). Similarly, results from a switchgrass yield response to $\mathrm{N}$ and $\mathrm{P}$ study conducted in Iowa indicated no response to $\mathrm{P}$ application [8]. Conversely, though, Taylor and Allinson [9] found poor yield response of a number of warm-season grasses (including switchgrass) to applications of $\mathrm{N}$ only compared to the responses of these grasses when both $\mathrm{N}$ and 
P were applied. Rehm [10] also reported a significant linear relationship between switchgrass yield and $\mathrm{N}$ and $\mathrm{P}$ applications. It is noteworthy to emphasize that while these studies focused on agronomic relationships, neither of them considered the benefits and costs associated with P application to phosphorus-deficient soils.

There is a substantial body of published literature that reports that a significant portion of the soils in the southern Great Plains are phosphorus deficient and responsible for limiting the yield (and the economic potential) of many crops that are commonly produced in the region [11-15]. In addition, a number of economic studies have been published that reported that crops common to the region require application of $\mathrm{N}$ and $\mathrm{P}$ fertilizers in order to achieve maximum economic success. For instance, economic analyses of several long-term agronomic field experiments conducted by the Agricultural Research Service on wheat, barley, corn, and other crops revealed that farmers can achieve greater economic net returns if the correct amount of $\mathrm{P}$ is applied to eliminate P deficiency [16]. In another example, Bauder [17] evaluated the economic benefits and costs for applying fertilizer on 11 different crops and found poor yield responses and net economic losses when $\mathrm{N}$ fertilizer was applied without $\mathrm{P}$ relative to the responses (and positive economic net returns) of the same crops when $\mathrm{P}$ was added with $\mathrm{N}$.

Despite the promotion of using switchgrass as a prime source of cellulosic feedstock for the large-scale conversion into bioenergy products in the southern Great Plains, little information is available regarding the economics of supplying $\mathrm{N}$ and $\mathrm{P}$ fertilizers for switchgrass production in phosphorusdeficient soil. To address this issue, data collected from agronomic field trials conducted in south-central Oklahoma were used to estimate expected values of production costs, gross revenue and net return to owner's labor, management, and overhead for eight $\mathrm{N}$ and $\mathrm{P}$ fertilizer supply systems. The objectives of this study were to determine the most economical fertilizer supply system for producing switchgrass feedstock in phosphorus-deficient soils in the southern Great Plains and to determine how sensitive the results are to favorable and non-favorable feedstock and fertilizer price scenarios. Information gleaned from this research will be valuable to farmers who may be interested in growing switchgrass as a bioenergy feedstock crop and to production scientists and extension educators working towards developing best management practices for producing and managing healthy stands of switchgrass in the southern Great Plains.

\section{Materials and Methods}

\section{Agronomic}

In 2007, Alamo switchgrass plants were established at two locations that were deemed to be deficient in phosphorus via intensive soil sampling and testing. Results from a Mehlich III extractant test revealed that soil $\mathrm{P}$ levels tested at $0-15$ and $15-30-\mathrm{cm}$ depths at the Ardmore, OK $\left(34^{\circ} 10^{\prime} \mathrm{N} / 97^{\circ} 8^{\prime}\right.$ W) site were 16 and $10 \mathrm{kgha}^{-1}$, respectively, and were 16 and $21 \mathrm{kgha}^{-1}$ at the Waurika, OK $\left(34^{\circ} 10^{\prime} \mathrm{N} / 97^{\circ} 47^{\prime} \mathrm{W}\right)$ site. To provide some perspective, the Oklahoma State Extension Service deems soil to be phosphorus deficient for the coolseason forage crops (cereal rye and wheat) and warm-season forage crops (bermudagrass) that are common to the region when soil P levels are below $44 \mathrm{kgha}^{-1}$ [18]. It is noteworthy to emphasize that switchgrass is known to have a very large and deep root system and is known to be very efficient in extracting soil $\mathrm{P}$; therefore, it is possible that roots could extract soil $\mathrm{P}$ up to $150 \mathrm{~cm}$. However, a study conducted in Alabama [19] reported that $90 \%$ of switchgrass roots were in the top $0-15 \mathrm{~cm}$ of soil when measured within rows, and $68 \%$ of switchgrass roots were in the top $0-15 \mathrm{~cm}$ of soil when measured between rows. This finding and the results from the soil tests help support the argument that the two sites utilized in this study were deficient in P.

Prior to establishment of switchgrass at the two study sites - sites previously used for producing cool-season cereal forages for growing stocker cattle - seed bed preparation was conducted by discing the study sites twice at a depth of 0 $15 \mathrm{~cm}$ and then cultivating them using a field cultivator. Switchgrass seed was planted at a rate of $5.6 \mathrm{~kg}$ of pure live seed per hectare on 15 May 2007 at Ardmore and on 17 May 2007 at Waurika locations using an SS-series Brillion seeder (Brillion Farm Equipment, Brillion, WI, USA). A single application (3.51 $\mathrm{Lh}^{-1}$ ) of 2,4-D Amine (2,4-dichlorophenoxyacetic acid, dimethyl amine) was applied in July to control broad-leaved weeds of all plots. A randomized complete block design with a split-plot arrangement of $\mathrm{N}$ rates on whole plots and $\mathrm{P}$ rates as sub-plots with four replications was set up and used at each site, providing for 8 site-years of agronomic data. Four rates of $\mathrm{P}\left(0,34,67\right.$, and $\left.101 \mathrm{kgha}^{-1}\right)$ and two rates of $\mathrm{N}$ $\left(0\right.$ and $\left.135 \mathrm{kgha}^{-1}\right)$ were broadcast on $2.4 \times 6.1-\mathrm{m}$ plots on 21 April 2008, 3 March 2009, 26 March 2010, and 4 April 2011 at Ardmore, respectively, and 17 April 2008, 11 March 2009, 29 April 2010, and 6 April 2011 at Waurika, respectively. N was applied in the form of urea (46-0-0) and $\mathrm{P}$ in the form of $\mathrm{P}_{2} \mathrm{O}_{5}(0-46-0)$. To account for near-deficient levels of $\mathrm{K}$ (and to ensure that potassium would not limit yield over the life of the study), blanket applications of K (0-0-60) were broadcast on the same dates that $\mathrm{N}$ and $\mathrm{P}$ were applied in each year on all plots at both locations at a rate of $135 \mathrm{kgha}^{-1}$ year $^{-1}$. No fertilizer was applied, and no biomass was harvested on any of the plots during the establishment year as recommended for stand longevity [20]. Switchgrass was harvested in 2008, 2009, 2010, and 2011 with either a Carter forage harvester or a HEGE forage plot harvester at a $10-\mathrm{cm}$ height at least 30 days after plant senescence (in December or January after a hard freeze). Comprehensive details about the field trials and, 
more specifically, the agronomic relationships between biomass yield and quality and the $\mathrm{N}$ and $\mathrm{P}$ treatments, $\mathrm{N}, \mathrm{P}$, and $\mathrm{K}$ removal levels for each year and location are reported in Kering et al. [21].

\section{Economic}

Standard enterprise budgeting techniques were used to estimate expected values for production costs, gross revenue, and net return to operator's labor, management, and overhead for the eight fertilizer supply systems. The eight systems (with the first number representing the level of $\mathrm{N}$ application (in kilograms per hectare per year) and the second representing the level of $\mathrm{P}$ application (in kilograms per hectare per year)) included: a zero fertilizer check system $(0 / 0)$, three $P$ systems $(0 / 34,0 / 67$, and $0 / 101)$, one $\mathrm{N}$ system (135/0), and three $\mathrm{N}$ and $\mathrm{P}$ systems (135/34, 135/67, and 135/101). Budgeting included costs associated with establishment of switchgrass and the annual costs associated with stand maintenance and production of bioenergy feedstock. Establishment costs included seed bed preparation activity (discing and field cultivation), seed and seed planting, herbicide and herbicide application, and an assumed land rental rate. The budgeted costs of all field operations (seedbed preparation, pesticide and fertilizer application, and harvesting activity) were based on published state average custom rates [22]. The estimated cost of establishing switchgrass was amortized over a 10 -year expected life of the stand.

Annual production costs included costs of fertilizer (N, P, and $\mathrm{K}$ ) and fertilizer application, costs of harvesting (mowing, raking, baling into large square bales, and staging), and annual operating interest. The prorated establishment costs and land rent were fixed for each year of the study. The costs for cutting, raking, hauling, and stacking baled feedstock were treated as a per-hectare fixed cost; however, the cost of baling large square bales of feedstock was considered a function of biomass yield, and so it varied by fertilizer supply system. A complete list of prices, custom rates, interest rates, and other assumptions used to calculate expected costs in the budgeting process is provided in Table 1.

At present, there are no commercial biorefineries that purchase switchgrass feedstock from producers in the southern Great Plains, effectively making the market farm-gate price for feedstock equal to zero. As a result, net return for each fertilizer supply system was calculated first using a base-case farm-gate feedstock price of $\$ 110 \mathrm{Mg}^{-1}$ and basecase prices of $\$ 1.28$ and $\$ 1.17 \mathrm{~kg}^{-1}$ for $\mathrm{N}$ and $\mathrm{P}$, respectively. To account for uncertainty about the future market price of feedstock and for unpredictable volatility of the prices of fertilizers, sensitivity analysis was conducted to determine how the relative economic results between systems would be expected to change for relatively favorable and nonfavorable scenarios for the price of feedstock, $\mathrm{N}$ and $\mathrm{P}$.
Table 1 Prices for fertilizer and fertilizer application, seed, pesticide, custom machinery operation, land rental, interest rate, and stand life used for budgeting

\begin{tabular}{ll}
\hline Variables & Price $^{\mathrm{a}}$ \\
\hline $\mathrm{N}(46-0-0), \$ \mathrm{~kg}^{-1}$ & 1.28 \\
$\mathrm{P}(0-46-0), \$ \mathrm{~kg}^{-1}$ & 1.17 \\
$\mathrm{~K}(0-0-60), \$ \mathrm{~kg}^{-1}$ & 1.15 \\
Custom fertilizer application, $\$ \mathrm{ha}^{-1}$ & 13.20 \\
Switchgrass seed (Alamo), $\$ \mathrm{ha}^{-1}$ & 33.00 \\
Herbicide (2,4-D Amine), $\$ \mathrm{~L}^{-1}$ & 3.36 \\
Custom herbicide application, $\$ \mathrm{ha}^{-1}$ & 10.08 \\
Custom rate for dicing, $\$ \mathrm{ha}^{-1}$ & 23.90 \\
Custom rate for field cultivating, $\$ \mathrm{ha}^{-1}$ & 19.15 \\
Custom rate for mowing, $\$ \mathrm{ha}^{-1}$ & 24.98 \\
Custom rate for raking, $\$ \mathrm{ha}^{-1}$ & 9.59 \\
Custom rate for bailing, $\$ \mathrm{ha}^{-1}$ & 36.18 \\
Custom rate for hauling and stacking at farm gate, $\$ \mathrm{ha}^{-1}$ & 11.12 \\
Land rental rate, $\$$ ha $^{-1}$ & 123.55 \\
Switchgrass stand lifetime, years & 10 \\
Interest rate for long-term capital, \% & 6.25 \\
Annual operating interest rate, $\%$ & 6.75 \\
\hline
\end{tabular}

${ }^{\mathrm{a}}$ Market prices for N, P, K, seed, and herbicides were taken from local farm input suppliers in February 2012, and custom rates were taken from Doye and Sahs [22]

\section{Statistical}

Random-effects mixed ANOVA models were used to estimate the effects of fertilizer supply system on feedstock yield, total cost, total revenue, and net return using the MIXED Procedures in SAS [23, 24]. The fertilizer supply system was modeled as a fixed effect and site-year was treated as a random effect $[25,26]$. The null hypotheses of no random effect associated with (1) site-year, (2) replication (block), (3) the interaction between site-year and replication, and (4) the interaction between $\mathrm{N}$ treatment and replication were tested using a likelihood ratio (LR) test [25]. The test statistics for the LR test follows a chi-square $\left(X^{2}\right)$ distribution with degrees of freedom equal to the number of imposed restrictions (four in this case). The results of these LR tests indicated that the null hypotheses of no random effect for replication, the interaction between site-year and replication, and the interaction between $\mathrm{N}$ treatment and replication could not be rejected; however, the null hypothesis of no site-year random effect was rejected $\left(\mathrm{LR}=518, X^{2}=9.49 ; j=4\right)$.

Several studies focusing on estimating the relationships between crop yield and fertilizers have reported that the yield was not normally distributed; that is, data were reported to be skewed negative [27-29]. In addition, data reflecting yield response to varying levels of fertilizer have oftentimes been shown to have problems associated with 
heteroskedastic variances (i.e., greater yield variability associated with greater fertilizer rates) [27]. Moreover, Just and Weninger [30] reported that problems with nonnormally distributed yields may, in fact, be due to problems associated with heteroskedastic variances. In response to these potential issues, our data were subjected to econometric tests for normality and heteroskedasticity.

The D'Agostino-Pearson $K^{2}$ test (omnibus test) was used to determine if the data are normally distributed [31, 35]. The results of this test showed that the null hypothesis of normally distributed yield data could not be rejected $(P=$ 0.6792 ). To test the hypothesis that our data were homoscedastic across $\mathrm{N}$ and $\mathrm{P}$ treatments, a likelihood ratio test was employed [32-34]. The results of the LR test indicated that the null hypothesis of homoscedastic (equal) variances across fertilizer rates was rejected $\left(\mathrm{LR}=10.2 ; X^{2}=5.99 ; j=\right.$ 2 ). As a result, the mixed models were estimated using a repeated measures option that allowed the error terms in the model to vary by each fertilizer rate [34].

Fisher's protected $F$ test was used to determine differences between the fertilizer supply systems for yield, total cost, gross revenue, and net return. Systems that were determined to be different at a $95 \%$ level of confidence were subjected to least significant difference (LSD) tests to scrutinize system means in order to identify the most economical fertilizer supply system.

\section{Results and Discussions}

Yield, production costs, gross revenue and net return to owner's labor, management, and overhead are reported in Table 2. Results showed that, on average, over the 8 siteyears, yield responded to both $\mathrm{N}$ and $\mathrm{P}$. Significantly greater yield $(P<0.0001)$ was realized with the $135 / 101$ system compared to all other systems, and yield increased from 7.5 to $9.3 \mathrm{Mgha}^{-1}$ (a $24 \%$ increase) with the $0 / 101$ system compared to the no fertilizer $(0 / 0)$ check system. However, there was no significant difference found between mean yields obtained from the $0 / 0,0 / 34$, and $0 / 67$ systems, indicating that yield did not respond to relatively low applications of P. This result is similar to that found by Muir et al. [7] who reported lack of response by switchgrass to $P$ application rates of $0-40 \mathrm{kgha}^{-1}$ in north-central and southern Texas. Furthermore, yield increased from 9.3 to $11.6 \mathrm{Mg}$ $\mathrm{ha}^{-1}$ (or by $25 \%$ ) with the $135 / 101$ system compared to the $0 / 101$ system, indicating that $\mathrm{N}$ was also a limiting fertilizer for switchgrass production over the 8 site-years of data. In general, feedstock yield was greatest for all the supply systems that included $\mathrm{N}$ application compared to the systems that did not include $\mathrm{N}$.

Results showed that fertilizer supply system significantly affected $(P<0.0001)$ the total cost of production. Estimated total cost was greatest $(P<0.0001)$ for the $135 / 101$ system

Table 2 Average feedstock yield and expected values for production costs, gross revenue, and net return to owner's labor, management, and overhead for eight fertilizer supply systems

\begin{tabular}{|c|c|c|c|c|c|c|c|c|c|}
\hline \multirow[t]{2}{*}{ Yield and economic measurements } & \multicolumn{8}{|c|}{ Fertilizer supply system } & \multirow[t]{2}{*}{$P>F$} \\
\hline & $0 / 0^{\mathrm{a}}$ & $0 / 34$ & $0 / 67$ & $0 / 101$ & $135 / 0$ & $135 / 34$ & $135 / 67$ & $135 / 101$ & \\
\hline Feedstock yield $\left(\mathrm{Mgha}^{-1}\right)$ & $7.5 \mathrm{e}^{\mathrm{b}}$ & $7.7 \mathrm{de}$ & $7.7 \mathrm{de}$ & $9.3 \mathrm{~cd}$ & $10.2 \mathrm{bc}$ & $10.4 \mathrm{bc}$ & $10.7 \mathrm{ab}$ & $11.6 \mathrm{a}$ & $<0.0001$ \\
\hline Seedbed preparation (disk, cultivate) $\left(\$ \mathrm{ha}^{-1}\right)$ & 70.5 & 70.5 & 70.5 & 70.5 & 70.5 & 70.5 & 70.5 & 70.5 & - \\
\hline Pesticide application $\left(\$ \mathrm{ha}^{-1}\right)$ & 32.4 & 32.4 & 32.4 & 32.4 & 32.4 & 32.4 & 32.4 & 32.4 & - \\
\hline Switchgrass seed and seed establishment $\left(\$ \mathrm{ha}^{-1}\right)$ & 207.3 & 207.3 & 207.3 & 207.3 & 207.3 & 207.3 & 207.3 & 207.3 & - \\
\hline Land rental: first year $\left(\$ \mathrm{ha}^{-1}\right)$ & 123.6 & 123.6 & 123.6 & 123.6 & 123.6 & 123.6 & 123.6 & 123.6 & - \\
\hline Total establishment cost $\left(\$ \mathrm{ha}^{-1}\right)$ & 433.8 & 433.8 & 433.8 & 433.8 & 433.8 & 433.8 & 433.8 & 433.8 & - \\
\hline $\begin{array}{l}\text { Establishment cost amortized @ } 6.25 \text { APR } \\
\text { for } 10 \text { years }\left(\$ \mathrm{ha}^{-1}\right)\end{array}$ & 59.6 & 59.6 & 59.6 & 59.6 & 59.6 & 59.6 & 59.6 & 59.6 & - \\
\hline Fertilizer application $(\mathrm{N}, \mathrm{P}, \mathrm{K})\left(\$ \mathrm{ha}^{-1}\right)$ & 169.0 & 208.3 & 247.6 & 286.9 & 341.0 & 380.3 & 419.6 & 458.9 & - \\
\hline Cutting, raking, baling, and staging $\left(\$ \mathrm{ha}^{-1}\right)$ & 246.1 & 252.3 & 248.1 & 294.9 & 321.5 & 326.9 & 335.5 & 359.6 & - \\
\hline Land rent: years $2-10\left(\$ \mathrm{ha}^{-1}\right)$ & 123.6 & 123.6 & 123.6 & 123.6 & 123.6 & 123.6 & 123.6 & 123.6 & - \\
\hline Interest on operating capital $\left(\$ \mathrm{ha}^{-1}\right)$ & 6.6 & 8.1 & 9.6 & 11.1 & 13.2 & 14.8 & 16.3 & 17.8 & - \\
\hline Establishment plus annual costs $\left(\$ \mathrm{ha}^{-1}\right)$ & $604.9 \mathrm{~g}$ & $651.9 \mathrm{fg}$ & $688.5 f$ & $776.1 \mathrm{e}$ & $858.9 \mathrm{~d}$ & $905.2 \mathrm{c}$ & $954.2 \mathrm{~b}$ & $1,019.5 \mathrm{a}$ & $<0.0001$ \\
\hline Gross revenue $\left(\$ \mathrm{ha}^{-1}\right)^{\mathrm{c}}$ & $825.0 \mathrm{e}$ & $847.0 \mathrm{de}$ & $847.0 \mathrm{de}$ & $1,023.0 \mathrm{~cd}$ & $1,122.0 \mathrm{bc}$ & $1,144.0 \mathrm{bc}$ & $1,177.0 \mathrm{ab}$ & $1,276.0 \mathrm{a}$ & $<0.0001$ \\
\hline $\begin{array}{l}\text { Net return to labor, management, and } \\
\text { overhead }\left(\$ \mathrm{ha}^{-1}\right)\end{array}$ & 220.1 & 195.1 & 158.5 & 246.9 & 263.1 & 238.8 & 222.4 & 256.5 & 0.6928 \\
\hline
\end{tabular}

${ }^{\mathrm{a}}$ The first number is kilograms of $\mathrm{N}$ per hectare, and the second number is kilograms of $\mathrm{P}$ per hectare

${ }^{\mathrm{b}}$ Means reported for yield, total cost, gross revenue, and net return for the systems marked with the same letter are not significantly different (LSD test, $\alpha=0.05$ )

${ }^{\mathrm{c}}$ Gross revenue was calculated using a base-case feedstock price of $110 \mathrm{Mg}^{-1}$ 
compared with the other seven systems. This seems to indicate that the costs of fertilizer and harvesting played a crucial role in the economics of feedstock production. Total estimated cost was $\$ 1,019.5 \mathrm{ha}^{-1}$ for the $135 / 101$ system. This cost included $\$ 59.6$ (6\% of the total) for establishment, $\$ 458.9$ (45\% of the total) for fertilizer and fertilizer application, \$359.6 (35\% of the total) for harvesting, \$123.6 (12\% of the total) for land rental, and $\$ 17.8$ (2\% of the total) for interest on operating capital. In addition, total cost increased by $28 \%$ for the $0 / 101$ system compared with the no fertilizer $(0 / 0)$ check system due to the cost of $\mathrm{P}$ application and harvesting activity.

Results showed that fertilizer system significantly affected $(P<0.0001)$ gross revenues in the base-case feedstock and fertilizer price scenario. Total estimated revenue $\left(\$ 1,276 \mathrm{ha}^{-1}\right)$ was greater for the $135 / 101$ system compared to all other systems, indicating that a greater revenue can be achieved with the system that generates the greatest yield (i.e., the $135 / 101$ system). On average, all systems with $135 \mathrm{~kg}$ of $\mathrm{N}$ treatment (135/0,135/34, 135/67, and 135/101) provided greater revenues than the systems with $0 \mathrm{kgha}^{-1}$ of $\mathrm{N}$ application (i.e., the $0 / 0,0 / 34,0 / 67$, and $0 / 101$ systems).

Average net returns for the base-case feedstock and fertilizer price scenario were not significantly different $(P=0.6928)$ among fertilizer systems; however, the $135 / 0$ system did realize the greatest numerical net return of $\$ 263.1 \mathrm{ha}^{-1}$. The 135/0 system resulted in $\$ 43 \mathrm{ha}^{-1}(20 \%)$ more net return compared with the no-fertilizer check system and $\$ 6.5 \mathrm{ha}^{-1}$ greater than the 135/101 system. This result indicates that the additional benefits from the additional yield generated from the $\mathrm{P}$ treatment in the $135 / 101$ system did not cover the expenses with its application nor the expenses with the additional harvesting activity associated with the extra yield obtained. Net returns were greater for all the systems with $135 \mathrm{~kg}$ of $\mathrm{N}$ treatment $(135 / 0,135 / 34,135 / 67$, and 135/101) compared with the systems with no $\mathrm{N}$ treatment (i.e., the $0 / 0$, $0 / 34,0 / 67$, and $0 / 101$ systems), indicating that producers in this region would be better off applying $\mathrm{N}$ but not $\mathrm{P}$ to switchgrass produced for bioenergy feedstock in phosphorusdeficient soil. This result lies in direct contrast to current recommendations for supplying fertilizers on traditional warm- and cool-season crops commonly used in the region for livestock needs. However, we emphasize that this result is not valid for switchgrass that is managed as a forage crop for livestock - it is only valid for a switchgrass crop that is being managed and harvested for bioenergy feedstock.

Table 3 reports how sensitive net returns are across systems to favorable and non-favorable scenarios for prices of feedstock, N and P. For a favorable market price scenario where the farm-gate price of feedstock was relatively high $\left(\$ 165 \mathrm{Mg}^{-1}\right)$ and prices of $\mathrm{N}$ and $\mathrm{P}$ are relatively low $\left(\$ 0.77 \mathrm{~kg}^{-1}\right)$, estimated net return was greatest $(P<0.0001)$ for the 135/101 system compared with all the other seven systems. The 135/101 system resulted in $\$ 112 \mathrm{ha}^{-1}$ (12\%) more net return compared with the one $\mathrm{N}$ system $(135 / 0)$. This indicates that producers would be better off applying $\mathrm{N}$ and $\mathrm{P}$ if they anticipate a favorable price scenario for feedstock and fertilizers. In this case, producers received a higher price for feedstock, and the benefits from the additional yield generated from the $\mathrm{P}$ treatment in the 135/101 system were enough to offset the additional expenses associated with fertilizer application and additional harvesting activity.

For an unfavorable market price scenario where the farmgate price of feedstock was relatively low $\left(\$ 55 \mathrm{Mg}^{-1}\right)$ and prices for $\mathrm{N}$ and $\mathrm{P}$ were relatively high $\left(\$ 2.20 \mathrm{~kg}^{-1}\right)$, average

Table 3 Expected values of net return to owner's labor, management, and overhead for a range (favorable to unfavorable) of price scenarios for feedstock, N, P for eight fertilizer supply systems $\left(\$ \mathrm{ha}^{-1}\right)$

\begin{tabular}{|c|c|c|c|c|c|c|c|c|c|c|c|c|}
\hline \multirow[t]{2}{*}{ Price scenario } & \multicolumn{3}{|l|}{ Prices } & \multicolumn{8}{|c|}{ Fertilizer supply system } & \multirow[t]{2}{*}{$P>F$} \\
\hline & $\begin{array}{l}\text { Feedstock } \\
\$ \mathrm{Mg}^{-1}\end{array}$ & $\begin{array}{l}\mathrm{N} \\
\$ \mathrm{~kg}^{-1}\end{array}$ & $\begin{array}{l}\mathrm{P} \\
\$ \mathrm{~kg}^{-1}\end{array}$ & $0 / 0^{\mathrm{a}}$ & $0 / 34$ & $0 / 67$ & $0 / 101$ & $135 / 0$ & $135 / 34$ & $135 / 67$ & $135 / 101$ & \\
\hline \multirow[t]{4}{*}{ Favorable } & 165 & 0.77 & 0.77 & $633 c^{b}$ & $632 \mathrm{c}$ & $610 \mathrm{c}$ & $800 \mathrm{bc}$ & $895 \mathrm{ab}$ & $900 \mathrm{ab}$ & $910 \mathrm{ab}$ & $1007 \mathrm{a}$ & $<0.0001$ \\
\hline & 165 & 1.28 & 1.17 & $633 b c$ & $619 b c$ & $582 \mathrm{c}$ & $758 \mathrm{abc}$ & $824 a b$ & $811 \mathrm{ab}$ & $811 \mathrm{ab}$ & $895 \mathrm{a}$ & 0.0138 \\
\hline & 165 & 2.20 & 2.20 & $633 a$ & $582 \mathrm{a}$ & $510 \mathrm{a}$ & $650 \mathrm{a}$ & $695 a$ & $645 \mathrm{a}$ & $609 a$ & $657 \mathrm{a}$ & 0.7007 \\
\hline & 110 & 0.77 & 0.77 & $220 b c$ & $209 \mathrm{bc}$ & $186 \mathrm{c}$ & $288 \mathrm{abc}$ & $336 a b$ & $324 \mathrm{ab}$ & $323 \mathrm{ab}$ & $366 a$ & 0.0174 \\
\hline \multirow[t]{4}{*}{ Base-case } & 110 & 1.28 & 1.17 & $220 \mathrm{a}$ & $195 \mathrm{a}$ & $159 \mathrm{a}$ & $247 \mathrm{a}$ & $263 \mathrm{a}$ & $239 a$ & $222 \mathrm{a}$ & $257 \mathrm{a}$ & 0.6928 \\
\hline & 110 & 2.20 & 2.20 & $220 \mathrm{a}$ & $159 \mathrm{ab}$ & $86 \mathrm{bcd}$ & $138 \mathrm{abc}$ & $134 \mathrm{ab}$ & $73 \mathrm{bcd}$ & $21 \mathrm{~cd}$ & $19 \mathrm{~d}$ & 0.0030 \\
\hline & 55 & 0.77 & 0.77 & $-192 \mathrm{a}$ & $-215 \mathrm{ab}$ & $-237 b c$ & $-223 \mathrm{ab}$ & $-227 \mathrm{ab}$ & $-248 b c$ & $-267 \mathrm{c}$ & $-269 \mathrm{c}$ & 0.0002 \\
\hline & 55 & 1.28 & 1.17 & $-192 \mathrm{a}$ & $-228 \mathrm{ab}$ & $-265 b c$ & $-265 b c$ & $-298 \mathrm{c}$ & $-333 d$ & $-366 \mathrm{e}$ & $-381 \mathrm{e}$ & $<0.0001$ \\
\hline Unfavorable & 55 & 2.20 & 2.20 & $-192 \mathrm{a}$ & $-265 b$ & $-337 \mathrm{c}$ & $-373 c$ & $-427 d$ & $-576 \mathrm{e}$ & $-568 \mathrm{e}$ & $-619 f$ & $<0.0001$ \\
\hline
\end{tabular}

${ }^{a}$ The first number is kilograms of $\mathrm{N}$ per hectare, and the second number is kilograms of $\mathrm{P}$ per hectare

${ }^{\mathrm{b}}$ Means within the same price scenario marked with the same letter are not significantly different (LSD test, $\alpha=0.05$ ) 
net returns for all eight fertilizer management systems were negative. Under this type of price regime, producers would not be willing to produce switchgrass as a bioenergy feedstock on their farms. Overall, the results show that the expected profitability was quite sensitive to the farm-gate price of feedstock and prices of $\mathrm{N}$ and $\mathrm{P}$.

\section{Conclusions and Limitations}

Economic information reporting how to best manage $\mathrm{N}$ and $\mathrm{P}$ fertilizers on established stands of switchgrass in phosphorusdeficient soils is limited. Eight site-years of agronomic data collected on phosphorus-deficient soils in south-central Oklahoma were used to evaluate eight alternative $\mathrm{N}$ and $\mathrm{P}$ fertilizer management systems. The results revealed that the greatest yield was realized with a fertilizer application system that utilized 135 and $101 \mathrm{kgha}^{-1}$ of $\mathrm{N}$ and $\mathrm{P}$, respectively. However, the economic results showed that the average benefits from this system did not outweigh the average costs associated with $\mathrm{N}$ and $\mathrm{P}$ application and additional harvesting activity associated with the additional yield response. The economic results suggest that phosphorus-deficient soils do not seem to have the same impact on switchgrass profitability as they do on the profitability of other crops traditionally produced by farmers in this region, such as bermudagrass pastures used to support cows and annual cool-season cereal pastures used for stocker cattle grazing. Moreover, the results support the agronomic findings from other published research that nitrogen applications do have a significant positive effect on switchgrass yields even under low $\mathrm{P}$ levels.

One limitation of this research is that the field experiments only included two levels of $\mathrm{N}$ and only four levels of P. Additional $\mathrm{N}$ and $\mathrm{P}$ treatments would allow for the estimation of a continuous, multivariate switchgrass yield response to $\mathrm{N}$ and $\mathrm{P}$ function that could then be used to determine the economically optimal rates of $\mathrm{N}$ and $\mathrm{P}$ that will maximize profitability.

Open Access This article is distributed under the terms of the Creative Commons Attribution License which permits any use, distribution, and reproduction in any medium, provided the original author(s) and the source are credited.

\section{References}

1. U.S. Environmental Protection Agency (2010) Renewable fuel standard program (RFS2) Regulatory Impact Analysis, EPA-420R-10-006

2. Sanderson MA, Adler PR (2008) Perennial forages as second generation bioenergy crops. Int J Mol Sci 9:768-788
3. Haque M, Epplin FM, Taliaferro CM (2009) Nitrogen and harvest frequency effect on yield and cost of four perennial grasses. Agron J 10:1463-1469

4. Vogel KP, Brejda JJ, Walters DT, Buxton DR (2002) Switchgrass biomass production in the Midwest USA: harvest and nitrogen management. Agron J 94:413-420

5. Stout WL, Jung GA, Shaffer JA (1988) Effects of soil and nitrogen on water use efficiency of tall fescue and switchgrass under humid conditions. Soil Sci Soc Am J 8(52):429-434

6. Guretzky J, Biermacher JT, Cook B, Kering M, Mosali J (2011) Switchgrass for forage and bioenergy: harvest and nitrogen rate effects on biomass yields and nutrient composition. Plant Soil 339 (1-2):69-81

7. Muir JP, Sanderson MA, Ocumpaugh WR, Jones RM, Reed RL (2001) Biomass production of 'Alamo' switchgrass in response to nitrogen, phosphorus, and row spacing. Agron J 93:896-901

8. Hall KF, George JR, Riedl RR (1982) Herbage dry matter yields of switchgrass, big bluestem, and Indianagrass with $\mathrm{N}$ fertilization. Agron J 74:47-51

9. Taylor RW, Allinson DW (1982) Response of three warm-season grasses to varying fertility levels on five soils. Can J Plant Sci 62:657-665

10. Rehm GW (1984) Yield and quality of a warm-season grass mixture treated with N, P, and atrazine. Agron J 76:731-734

11. Mullen RW, Freeman KW, Johnson GV, Raun WR (2001) The Magruder plots-long-term wheat fertility research. Better Crops 85(4):6-8

12. Zhang H (2008) Oklahoma agricultural soil test summary 2004 2008. Oklahoma State University, Oklahoma Cooperative Extension Service, CR-2259

13. Johnson G, Zhang H (2004) Sulfur requirements of Oklahoma crops. Oklahoma State University, Oklahoma Cooperative Extension Fact Sheets, PSS-2237

14. Miller TD (1998) Deep phosphorus banding in winter wheat-a risk management tool for the Southern Great Plains. Better Crop 8 (4):26-28

15. Diaz DAR, Mengel DB, Martin KL (2011) Phosphorus facts-soil, plant, and fertilizer. Kansas State University Agricultural Experiment Station and Cooperative Extension Service, C-665

16. Elstein D (2004) Phosphorus fertilizer can be effective for many years. News and Events. Agricultural Research Service, USDA. http:// www.ars.usda.gov/is/pr/2004/040126.htm. Accessed 12 July 2011

17. Bauder J (1996) The cost (or benefit) of applying phosphorus fertilizer. Extension soil and water quality specialist at Montana State University. Agronomy Note 2, weekly news release and fact sheet series, 1995-1996

18. Zhang H, Raun B (2006) Oklahoma soil fertility handbook, 6th edn. Oklahoma Cooperative Extension Service, Oklahoma State University, Stillwater

19. Ma Z, Wood CW, Bransby DI (2000) Impacts of soil management on root characteristics of switchgrass. Biomass Bioenergy 18:105112

20. Lawrence J, Cherney J, Barney P, Ketterings Q (2006) Establishment and management of switchgrass. Cornell University Cooperative Extension. Fact sheet 20. http://forages.org/bioenergy/ downloads/Switchgrassfactsheet20.pdf. Accessed 26 January 2010

21. Kering MK, Biermacher JT, Twain TJ, Mosali J, Guretzky JA (2012) Biomass yield and nutrient responses of switchgrass to phosphorus application. Bioenergy Res 5:71-78. doi:10.1007/ s12155-011-9174-y

22. Doye D, Sahs R (2010) Oklahoma farm and ranch custom rates, 2009-2010. Oklahoma State University, Oklahoma Cooperative Extension Service, CR-205 (0310 Rev)

23. Littell RC, Milliken GA, Stroup WW, Wolfinger RD (1996) SAS system for mixed models. SAS Inst., Cary

24. SAS Institute (2008) SAS/STAT. SAS system for Windows. v. 9.2. SAS Inst, Cary 
25. Biermacher JT, Brorsen BW, Epplin FM, Solie JB, Raun WR (2009) The economic potential of precision nitrogen application with wheat based on plant sensing. Agric Econ 40:397407

26. Tembo G, Brorsen BW, Epplin FM (2008) Crop input response functions with stochastic plateaus. Am J Agric Econ 90(2):424434

27. Bharat MU, Smith EG, Favret LM (2006) An innovative approach for modeling crop yield response to fertilizer nutrients. CEACAES annual meeting, Montreal, Quebec, May 25-28

28. Swinton S, King RP (1991) Evaluating robust regression techniques for detrending crop yield data with non-normal errors. Am J Agric Econ 73:446-461

29. Ramirez OA (1997) Estimation and use of multivariate parametric model for simulating heteroscedastic, correlated, non-normal random variables: the case of corn belt corn, soybean and wheat yields. Am J Agric Econ 79:291-305
30. Just RE, Weninger Q (1999) Are crop yields normally distributed? Am J Agric Econ 81:287-304

31. Kapiamba LF (2005) Modeling heteroskedasticity of crop yield distributions: implications for normality. AAEA Annual Meetings, Providence, Rhode Island, July 24-27

32. Greene WH (2008) Econometric analysis. Hypothesis and specification tests and fit measures, 6th edn. Pearson Education, Inc., Upper Saddle River, pp 498-500

33. Biermacher JT, Epplin FM, Brorsen BW, Solie JB, Raun WR (2009) Economic feasibility of site-specific optical sensing for managing nitrogen fertilizer for growing wheat. Precis Agric 10:213-230

34. Boyer CN, Brorsen W, Solie JB, Raun WR (2011) Profitability of variable rate nitrogen application in wheat production. Precis Agric 12:473-487. doi:10.1007/s11119-010-9190-5

35. D'Agostino RB, Belanger A, D'Agostino RB Jr (1990) A suggestion for using powerful and informative tests of normality. Am Stat 44(4):316-321 